\title{
BUILDING CUSTOMER RELATIONSHIPS AS RETENTION STRATEGY IN THE SOUTH AFRICAN DOMESTIC PASSENGER AIRLINE INDUSTRY
}

\author{
Pierre Mostert: WorkWell Research Unit for Economic and Management Sciences, North-West \\ University \\ Christine De Meyer: North-West University
}

\begin{abstract}
SYNOPSIS
Organisations are increasingly focusing on building long-term relationships with customers, thereby increasing their probability for success by offering customers higher levels of satisfaction, increasing customer loyalty, and ultimately retaining customers. Airlines in particular can benefit from retaining customers as the airline industry is characterised by fierce competition and many airlines are finding it difficult to survive against the backdrop of enormous challenges in the past decade, including the significant decline in demand for air travel together with rising costs and the worldwide economic downturn.
\end{abstract}

This study investigates the effect which a strategy by airlines of building relationships with customers has on customer satisfaction, loyalty, and ultimately customer retention. The effect of service failures on customers' relationships with airlines are also considered as a negative experience could results in customers defecting to competitors.

A questionnaire, comprising six sections, was specifically compiled to determine customer retention in the South African domestic passenger airline industry. Data were collected by trained fieldworkers from OR Tambo International Airport by means of a non-probability convenience sampling method from 324 passengers flying with the various domestic airlines.

Findings indicate that most respondents were satisfied with the airlines' overall service; respondents who formed relationships with domestic airlines were more loyal toward the airlines; and the relationships of respondents who were satisfied with airlines' service recovery efforts were either strengthened or unchanged.

The findings from this study support findings from international studies by providing a unique South African perspective on the effect of a strategy of building relationships with customers on their satisfaction, loyalty and ultimately retention. It can therefore be recommended that the organisations competing in the South African service sector, and specifically the domestic airline industry, make special efforts to build relationships with existing customers, rather than to continually try to acquire new customers. This strategy could result in a higher probability of success by increasing customer satisfaction, customer loyalty, and ultimately customer retention.

Key words: Customer relationships, satisfaction, loyalty, retention, service failure, service recovery, airline industry

\section{INTRODUCTION}

Marketers are increasingly shifting their focus to relationship marketing as they realise that by building long-term relationships with customers, organisations' success can be greatly improved by ultimately retaining these customers (Xu, Goedegebuure \& van der Heijden, 2006:82; Keith, Lee \& Lee, 2004:4). However, Zeithaml, Bitner and Gremler (2009:104) argue that many organisations often fail to build relationships with their customers by rather focusing on acquiring new customers - a practice that does not make a lot of business sense as it is widely accepted that it is far more expensive to continually attract new customers than to retain exiting ones (Magnini \& Ford, 2004:280; Hill \& Alexander, 2002:13; Murphy, 2001:1-2).

One industry in particular that could benefit from building relationships with their customers in an effort to retain them, is the vulnerable airline industry. Airlines are finding it difficult to survive against the backdrop of enormous challenges in the past decade, including the significant decline in demand for air travel since the September 2001 terrorist attacks in the US, the 2003 outbreak of Severe Acute Respiratory Syndrome (SARS), and more recently concerns regarding the possible impact of the H1N1 virus (also known as Swine Flue) on air travel (Associated Press, 2009; Gopalakrishnan, 2009; Gursoy, Chen \& Kim, 2005:57). The worldwide economic downturn has, in addition to rising costs, further contributed to the economic challenges in the airline industry that resulted in a number of airlines ceasing its operations, 
such as U.S. carriers ATA Airlines, Skybus Airlines, Maxjet, Aloha Airgroup, and Champion Air, Hong Kong's Oasis Hong Kong as well as South Africa's Nationwide Airlines (Starmer-Smith, 2008; Theunissen \& Sguazzin, 2008).

The declining demand and financial turmoil is expected to continue (if not worsen) in the foreseeable future, with predictions suggesting that demand for passenger traffic will drop by $5.7 \%$ and for cargo by 13\% during 2009 (Associated Press, 2009). This bleak outlook led to the International Air Transport Association (IATA), representing 230 airlines worldwide, changing its forecast for global airline losses for 2009 from $\$ 4.7$ billion in March to $\$ 9$ billion only three months later in June 2009 (Associated Press, 2009; Gopalakrishnan, 2009).

Although organisations increasingly focus on customer satisfaction to retain their customers, Cursai and Kennedy (2002:340) warn that satisfaction alone is not enough, since satisfied customers sometimes defect to competitors. Organisations should therefore, in addition to offering customers greater levels of satisfaction, increasingly focus on growing customer loyalty by building relationships with them (Ahmad \& Buttle, 2002:150; Cursai \& Kennedy, 2002:340; Miller, Craighead \& Karwan, 2000:398). Pakdil and Aydin (2007:236) contend that airlines should, due to the highly competitive industry in which they operate, not only offer high quality service to their passengers but also attempt to increase loyalty and retain customers in an effort to ensure their success.

The purpose of this article is to determine the effect which a strategy of building relationships with customers has on customer satisfaction, loyalty and ultimately retention in the South African domestic passenger airline industry. The article will also consider the influence of service failures on passengers' relationships with airlines, as this negative outcome from service delivery could adversely influence customer retention in the airline industry.

\section{THEORETICAL BACKGROUND}

\section{Relationship Marketing}

Relationship marketing can, for the purpose of this study, be defined as the establishment and maintenance of long-term relationships between an organisation and its customers (Torres \& Kline, 2006:293; Reinartz \& Kumar, 2003:77; Christopher, Payne \& Ballantyne, 2002:4). The essence of relationship marketing can therefore be seen as building long-term relationships with customers rather than to continually attempt to attract new customers (Reinartz \& Kumar, 2003:77).

Relational exchange relationships emerge when organisations and their customers develop interactive, mutually beneficial, long-term relationships (Xu et al., 2006:82; Venetis \& Ghauri, 2004:1579). In contrast, Venetis and Ghauri (2004:1579) explain that customers seeking a transactional relationship with an organisation are more inclined to buy from multiple suppliers, switch more frequently between suppliers, and buy on the basis of price.

Organisations can reap numerous benefits from building relationships with customers (Hansemark \& Albinsson, 2004:41; Keith et al., 2004:24-25; Venetis \& Ghauri, 2004:1578), including: increasing customer satisfaction as customers' perceptions of the value they receive increase; lower marketing costs; customers are more likely to support the organisation in the future as their satisfaction increases; increased effectiveness because of knowledge of the customer; increased customer dependence on the organisation; increased customer retention rates, and ultimately higher profits. Benefits to customers, include the following: they may feel more valuable if the organisation recognises them and addresses them by name; customers may have a decrease in risk (e.g. physical, social, financial or psychological risk) associated with dealing with the organisation; customers may experience higher status by being associated with an organisation; personalisation of products or services offered; and customers may perceive greater satisfaction with the organisation (Buttle, 2004:26-27; Keith et al., 2004:24-25; Venetis \& Ghauri, 2004:1578).

It can be concluded that relationships hold benefits for the organisation and its customers and organisations should increasingly focus on building relationships with customers in an effort to better their 
results by identifying, satisfying, and retaining their most profitable customers (Buttle, 2004:16; Hansemark \& Albinsson, 2004:41).

\section{Customer Satisfaction}

Customer satisfaction, for the purpose of this study, refers to customers' evaluation of a service in terms of whether the service has met or exceeded their needs and expectations (Zeithaml et al., 2009:104; Hoffman et al., 2005:329). McDougall and Levesque (2000:393) state that customer satisfaction should be viewed as customers' overall evaluation of the service provider. This view of customer satisfaction is especially applicable to the airline industry, due to the many activities involved in the service delivery process. For example, airline passengers would probably rate their satisfaction with an airline by considering the airline's ground staff and cabin crews on their courteousness, helpfulness and competence; sufficient and efficient check-in services; waiting lounges; keeping to departure and arrival times; quality food and beverages served during the flight; in-flight entertainment and online services offered. Airlines should therefore understand what customer expectations are to ensure that they provide quality service (Gilbert \& Wong, 2003:519). Failure to meet customer expectations on any one of the many service delivery processes could lead to a service failure which, in turn, will influence customers' satisfaction.

It was postulated by Fečiková (2004:57) that customers who are satisfied with the service are more likely to return to the organisation, opposed to dissatisfied customers who would probably switch to an alternative. Zeithaml et al. (2009:109) and Ranaweera and Prabhu (2003:374-375) add that increased levels of customer satisfaction have been linked to customer loyalty and will ultimately result in higher rates of customer retention. However, Hui, Wan and Ho (2007:974), Xu et al. (2006:97), Hansemark and Albinsson (2004:40-57) and Jones and Sasser (1995:89) caution that although there appears to be a positive link between customer satisfaction and loyalty, this relationship is not linear and satisfied customers may defect to competitors. By noting this concern, organisations should rather focus on determining which particular elements of service enhances loyalty in customers - because loyal customers are more easily retained (Reichheld, 1996:58).

\section{Customer Loyalty}

Loyalty refers to customers' commitment to repeat past purchases of a preferred service over time (Peelen, 2005:32), even if other more convenient or suitable alternatives exist (McMullan \& Gilmore, 2003:231). Although it seems a relatively simplistic concept, Zikmund, McLeod and Gilbert (2003:77) assert that loyalty is in fact a complex, multi-faceted issue that involves more than the repetition of certain behaviour. Kumar and Reinartz (2006:163) and Buttle (2004:21) agree with this view by explaining that customer loyalty should be defined or measured in one of two broad approaches, namely behavioural loyalty and attitudinal loyalty.

Behavioural loyalty considers customers' purchasing behaviour by tracking their continued support in terms of the consistency of their purchase from the organisation (Zikmund et al., 2003:69). A major shortcoming of this approach is that it does not indicate why an organisation was selected because repeat purchases are not made by virtue of true loyalty, but might be based on factors such as price, convenience, availability or habit (Zikmund et al., 2003:70).

It was also suggested by Zikmund et al. (2003:70) and Buttle (2004:22) that loyalty involves more than just repeat purchases and can include an attitudinal dimension which includes customers' feelings, commitment and intentions to purchase over time. Customers who are more involved in or committed to an organisation would therefore be considered to be more loyal in attitudinal terms. The behavioural definition of customer loyalty is, however, often the preferred method to define and measure customer loyalty as sales and profits flow from customers' actions when buying from the organisation (Buttle, 2004:22).

Organisations should, rather than focusing on customer satisfaction, focus on customer loyalty as an indicator of customer retention. This becomes evident when considering the benefits of customer loyalty to the organisation. Loyal customers cannot easily be persuaded to defect to competitors, because of the fear that their needs and expectations will not be understood or met by another organisation (Murphy, 
2001:43). Organisations could furthermore compile more accurate forecasts because loyal customers are more predictable and consistent in their purchasing behaviour. Also, loyal customers are more likely to buy across product and service lines, thereby increasing the organisation's profitability (Ang \& Buttle, 2006:85; Faulkner, 2003:3), buy more of the product, advocate the product to others, and share knowledge and experiences with family and friends (Zikmund et al., 2003:71).

By considering the benefits of customer loyalty it becomes evident that organisations should endeavour to build customer loyalty in an effort to retain customers. Reichheld (1996:58) supports this view by suggesting that loyal customers can more easily be retained by organisations.

\section{Customer Retention}

The essence of customer retention is captured in the notion that organisations should focus their marketing efforts on existing customers (Hoffman, et al. 2005:339). Customer retention therefore implies that organisations should strive to form and maintain good relationships with customers (Gerpott, Rams \& Schindler, 2001:253) in an effort to continue doing business with them in the future (Murphy, Burton, Gleaves \& Kitshoff, 2006:60 \& 144).

The importance of customer retention is highlighted by considering the benefits it has for the organisation (Ang \& Buttle, 2006:85; Magnini \& Ford, 2004:280; Reichheld, 1996:57), including: lower acquisition costs, resulting in lower sales and marketing costs; profits are guaranteed from existing customers who are known to spend a certain minimum amount within a given period; obtain growth in "per customer" income as customer spending is likely to increase with the length of the relationship; reduced operating costs, since costs involved in keeping the customer can be distributed over a longer period of time; customers provide the organisation with referrals; and products can be sold at a higher price as customers do not wait for promotions or price reductions before they purchase.

From these benefits it can be concluded that customer retention is indeed critical to the organisation and could therefore directly influence the organisation's bottom line (Chi \& Qu, 2008:624; Fečiková, 2004:57). Organisations must therefore consider ways in which to improve their customer retention.

However, Page, Pitt, Berthon and Money (1996:822) posit that before organisations develop strategies to improve customer retention, they must first understand the reasons why customers defect. DeSouza (1992:25-26) suggests a number of reasons for customer defections, namely, price, product, market, technical and service reasons. Only price and service reasons will be further elucidated due to its prevalence in the airline industry.

Price reasons imply that customers defect when competitors offer lower prices. This is specifically prevalent in the airline industry (DeSouza, 1992:25-26) where customers often defect when they can obtain lower prices from competitors for comparable flights. Martin-Consuegra, Molina and Esteban (2007:461), however, warn that customers who are habitually looking for lower prices will be difficult to retain as they will defect as soon as they find a cheaper item elsewhere. Customers can also defect to competitors due to service reasons when they experience poor service from the organisation, often leading to a service failure (Seawright, DeTienne, Bernhisel \& Hoopes Larson, 2008:253). Despite organisations' efforts to deliver satisfactory service, service failures do occur and, if not adequately addressed, could cause customers to defect. This is especially applicable to the airline industry as airlines are prone to service failures due to the service processes airlines employ in service delivery (Bejou \& Palmer, 1998:8). It is therefore necessary to briefly expand on service failures as a possible cause for customer defection.

\section{Service Failure}

A service failure can be defined as a real or perceived service-related problem or where something has gone wrong when receiving a service (Maxham, 2001:11). The implication of a service failure is that the organisation has not met the customer's service expectations (Chan \& Wan, 2008:775), possibly leading to the customer perceiving a loss resulting from the failure (Patterson, Cowley \& Prasongsukarn, 2006:264). 
Despite organisations' best efforts to provide their customers with flawless service delivery, this is nearly impossible due to the human involvement in service delivery and consumption (Mattila \& Cragnage, 2005:271; Miller et al., 2000:387-400). Research by Bamford and Xystouri (2005:314) and Coye (2004:60) indicates that a number of causes for service failures in the airline industry can occur and includes: flight delays, cancellations or diversions, reservation problems, overbooking of flights or attitudes of ground and cabin staff.

A service failure could not only negatively impact on customers' confidence in the organisation, but could also result in customers defecting to a competitor (Cranage, 2004:210). Organisations should, therefore, identify areas in the service delivery process where service failures are possible together with processes to prevent failures from occurring in the future (Cranage, 2004:211; Ahmad, 2002:19).

Although it is unlikely that organisations can eliminate all service failures from occurring, they can attempt to maintain and even enhance customer satisfaction by effectively dealing with these failures through service recovery (Bamford \& Xystouri, 2005:307; Maxham, 2001:11; Miller et al., 2000:387).

\section{Service Recovery}

Service recovery can be defined as the actions taken by an organisation to correct service failures by reinstating customers' level of satisfaction and loyalty to ultimately retain these customers (Boshoff \& Klemz, 2005:1; Miller et al., 2000:388; Grönroos, 1990:7).

The importance of service recovery becomes clear when considering that poor or ineffective service recovery implies that the customer is disappointed twice. This could lead to the customer spreading negative word-of-mouth (Lewis \& McCann, 2004:8), rating the organisation lower than what they would have following the service failure (Maxham, 2001:12), losing confidence in the organisation, and could furthermore influence the decision as to whether to stay with the organisation or to defect to competitors (Boshoff \& Staude, 2003:9-10; Ahmad, 2002:24).

Effective service recovery, however, can lead to customers experiencing an even higher level of satisfaction than what they would have experienced, had the failure not occurred (Baron \& Harris, 2003:64; Boshoff \& Staude, 2003:9-10). An organisation's service recovery efforts could therefore enhance customer satisfaction and loyalty (Torres \& Kline, 2006:294; Magnini \& Ford, 2004:279), thereby directly influencing whether a customer stays with the organisation or defects to a competitor (Yuksel, Kilinc \& Yuksel, 2006:12). Coyles and Gokey (2005:105) emphasise the aforementioned by suggesting that customers who experienced satisfactory service recovery are just as loyal, if not more so, than those who have not experienced a service failure. The importance of offering satisfactory service recovery can therefore be summarised by considering that service recovery could possibly be seen as equal to, if not more important than, initially providing good service to customers (Eccles \& Durand, 1998:68).

Service recovery strategies that organisations can implement include apologising for the service failure and offering customers a tangible form of compensation, for example discounts or vouchers (Mattila \& Cranage, 2005:276; Boshoff \& Leong, 1998:40-42). It is stated by La and Kandampully (2004:394) and Boshoff and Staude (2003:11) that organisations should immediately recover the service failure when it occurs or offer customers alternative options that will meet their needs; ensure that personnel dealing with the service recovery is professional in their actions; and communicate with those customers who experienced the service failure by providing feedback and explaining why the service failure occurred.

Because they are susceptible to service failures, airlines must ensure that they have service recovery strategies in place in response to service failures. Christopher et al. (2002:60) support this view by stating that airlines will, through effective service recovery, strengthen relationships with customers and thereby minimise customer defections.

\section{PROBLEM STATEMENT AND RESEARCH HYPOTHESES}

With the current global economic crisis it is arguably more important than ever before for organisations to retain their customers. Customer retention is especially important in the struggling airline industry, where 
it is forecasted that African airlines will, compared to the loss of $\$ 100$ million during 2008 , lose an approximate $\$ 600$ million in 2009 (Associated Press, 2009).

Although some authors have suggested that customers can be retained by offering increased levels of satisfaction (Zeithaml et al., 2009:109; Ranaweera \& Prabhu, 2003:374-375), others have argued that there is not a linear relationship between the two concepts (Hui et al., 2007:974; Xu et al., 2006:97; Jones \& Sasser, 1995:89). Despite this discrepancy, it could be seen from the literature review that there appears to be an association between building long-term relationships with customers, customer satisfaction, customer loyalty and ultimately customer retention.

The purpose of this study is therefore to determine if, by building relationships with customers, airlines can achieve customer satisfaction and customer loyalty, which could ultimately lead to customer retention. The effect of service failures on customers' relationships with airlines will also be considered as negative service experiences could results in customers defecting to competitors.

Based on the literature review the following can be hypothesised:

$\mathrm{H}_{0} 1$ : Customers that South African domestic airlines are trying to form relationships with are not more satisfied with these airlines' overall service than those customers that airlines are not trying to form relationships with;

$\mathrm{H}_{0}$ 2: Customers who have formed relationships with South African domestic airlines are not more satisfied with these airlines' service offerings than those customers who have not formed a relationship;

$\mathrm{H}_{0} 3$ : Customers who have formed relationships with South African domestic airlines are not more loyal towards these airlines than those customers who have not formed a relationship;

$\mathrm{H}_{0} 4$ : Customers' satisfaction with South African domestic airlines' service recovery efforts will not influence their relationship with the airline.

\section{METHODOLOGY}

\section{Sample and Data Collection}

Since the various South African domestic airlines were not willing to provide their customer details, a nonprobability convenience sampling method was used to survey South African domestic passengers at OR Tambo International airport. Convenience sampling was chosen under the circumstances as it was the least expensive and least time consuming sampling method to gather large amounts of information (Malhorta, 2007:341). Self-administered questionnaires were randomly distributed by fieldworkers to passengers at the various domestic airline check-in counters. In an attempt to ensure that the data were not skewed by tourists or holiday makers, it was decided to conduct the fieldwork over a two-week period outside school holidays. Questionnaires were distributed from early morning to late evening to accommodate the departure times of the various South African domestic airlines.

\section{Measuring Instrument}

The questionnaire, comprising six sections, was specifically compiled to determine customer retention in the South African domestic passenger airline industry. Section A consisted of classification and screening questions (including determining how often respondents have flown with the domestic airline in the 12 months preceding the study and reasons for choosing an airline). Section B was devoted to service failures experienced by respondents when flying with the airline they most often fly with and the service recovery efforts offered by airlines to recovery from the failure. Section C measured respondents' satisfaction with the airlines' service by means of 26 service-related elements. Sections $D$ and $E$ determined respondents' relationships with, and loyalty towards the airline they most often fly with, while the final section captured respondents' demographic information.

\section{Data Analysis}

The hypotheses were tested by means of cross tabulations to determine if associations exist between a number of categorical variables (Cooper \& Schindler, 2008:459), including whether airlines have attempted to form relationships with respondents, whether respondents have formed a relationship with 
the airline they fly with most often, respondents' satisfaction with the airlines' overall service, respondents' loyalty towards the airlines and the effect of service failure and recovery on respondents' relationships with the airlines. The Pearson's Chi-square statistic was used and a value of $p<0.05$ was considered indicative of statistical significance (Reid, 1987:113) when determining whether the values calculated for the cross-tabulations were statistically significant (Cooper \& Schindler, 2008:459, Malhotra, 2007:474).

\section{RESULTS}

\section{Sample Profile}

A total of 324 questionnaires could be used and most of the respondents flew with South African Airlines (33.3\%), followed by Kulula.com (21\%), Nationwide Airlines (15.4\%), Mango (14.5\%), 1-Time (7.4\%), South African Express (5.9\%) and South African Airlink (2.5\%). It should be noted that although Nationwide Airlines ceased operations in April 2008, results obtained from passengers flying with this airline were retained as the airline was still operational at the time of the study. Somewhat more males $(55.9 \%)$ than females $(44.1 \%)$ participated in the study. The greatest number of respondents $(65.4 \%)$ was between the ages of 20 and 40 with a further $20.1 \%$ between the ages of 41 and 50 . The majority of respondents have flown three to six times $(54.9 \%)$ or seven to 12 times $(28.2 \%)$ with a domestic airline in the 12 months preceding the study. Respondents either flew for business reasons (52.5\%), going on holiday $(30.9 \%)$, visiting friends or relatives $(14.5 \%)$ or some other reason $(2.2 \%)$. Most respondents either decided themselves which airline they fly with (49.4\%) or their business policy dictated which airline to use $(24.7 \%)$.

\section{HYPOTHESES TESTING}

\section{Relationship and Satisfaction with the Airline (Hypotheses 1 and 2)}

Respondents were asked to indicate whether the domestic airlines they fly with most often were trying to form relationships with them and also whether they have formed a relationship with these airlines. Whereas the majority of respondents (56.8\%) indicated that the domestic airlines were trying to form relationships with them, somewhat less than half $(43.8 \%)$ indicated that they have actually formed a relationship with the domestic airline. It could therefore be determined that $34.3 \%$ of respondents indicated that the airline wanted to form a relationship with them and who actually formed a relationship with the airline.

Respondents' satisfaction with the airlines' service was determined by rating each of the 26 servicerelated statements on a four-point Likert-type scale, labelled as 1 = "not satisfied at all"; 2 = "not satisfied"; 3 = "satisfied"; and 4 = "very satisfied". Respondents could also select a "not applicable" option, should they be unfamiliar with the service element (for example online service provided). To determine respondents' overall satisfaction with the airlines' service, the average mean scores for each respondent for the 26 service-related elements were calculated. Respondents with an average mean score of $\geq 3$ were considered to be satisfied with an airline's overall service efforts, while those with an average mean score of $\leq 2.99$ were considered to be dissatisfied with the airline's overall service. From this analysis, it was determined that $52.2 \%$ were satisfied and $47.8 \%$ dissatisfied with the overall service airlines offer.

The responses were further analysed to determine if a relationship exists between airlines who are trying to form relationships with respondents and respondents' overall satisfaction with the airline. Table 1 shows the results from a cross-tabulation between whether airlines are trying to form relationships with respondents and respondents' satisfaction with the airlines' service (see Table 1a in Annexure A for a detailed exposition of statistical values). 
Table 1: A cross-tabulation between whether airlines are trying to form relationships with respondents and respondents' satisfaction with the airlines' service

\begin{tabular}{|l|l|l|l|l|}
\cline { 3 - 5 } \multicolumn{2}{c|}{} & $\begin{array}{l}\text { Whether airlines are trying to form a } \\
\text { relationship }\end{array}$ & Total \\
\cline { 3 - 4 } \multicolumn{2}{c|}{} & $\begin{array}{l}\text { Airlines are trying to } \\
\text { form a relationship }\end{array}$ & $\begin{array}{l}\text { Airlines are not trying } \\
\text { to form a relationship }\end{array}$ & \\
\hline \multirow{2}{*}{$\begin{array}{l}\text { Satisfaction with } \\
\text { airlines' service }\end{array}$} & Satisfied & 116 & 53 & 169 \\
& & $68.6 \%$ & $31.4 \%$ & $100 \%$ \\
\cline { 2 - 5 } & Dissatisfied & 68 & 87 & 155 \\
& $43.9 \%$ & $56.1 \%$ & $100 \%$ \\
\hline Total & 184 & 140 & 324 \\
& & $46.8 \%$ & $43.2 \%$ & $100 \%$ \\
\hline
\end{tabular}

From the cross tabulation it can be seen that the majority of respondents who indicated that a domestic airline is trying to form a relationship with them were satisfied with the airline's overall service (68.6\%), while the majority of respondents who indicated that the airline was not trying to form a relationship with them were dissatisfied with the airline's overall service (56.1\%). The Pearson Chi-square test was performed to determine if a statistically significant association exists between whether airlines are trying to form relationships with respondents and respondents' overall satisfaction with the airline. The test realised an exceedance probability of $p 0.000$, indicating a statistically significant association between these variables. Hypothesis 1 should therefore be rejected as there is a statistically significant association between whether airlines are trying to form relationships with respondents and respondents' overall satisfaction with the airline

Responses were further analysed to determine if an association exists between whether respondents have formed a relationship with the airlines and their overall satisfaction with the airline. Table 2 provides the results from a cross-tabulation between whether respondents have formed relationships with the airlines and their satisfaction with the airlines' service (see Table 2a in Annexure A for a detailed exposition of statistical values).

Table 2: A cross-tabulation between whether respondents have formed relationships with the airlines and their satisfaction with the airlines' service

\begin{tabular}{|c|c|c|c|c|}
\hline & \multicolumn{2}{|c|}{ Whether relationship was formed } & \multirow[t]{2}{*}{ Total } \\
\hline & & $\begin{array}{l}\text { Have formed a } \\
\text { relationship }\end{array}$ & $\begin{array}{l}\text { Have not formed a } \\
\text { relationship }\end{array}$ & \\
\hline \multirow[t]{2}{*}{$\begin{array}{l}\text { Satisfaction with } \\
\text { airlines' service }\end{array}$} & Satisfied & $\begin{array}{l}84 \\
49.7 \% \\
\end{array}$ & $\begin{array}{l}85 \\
50.3 \%\end{array}$ & $\begin{array}{l}169 \\
100 \%\end{array}$ \\
\hline & Dissatisfied & $\begin{array}{l}58 \\
37.4 \%\end{array}$ & $\begin{array}{l}97 \\
62.6 \%\end{array}$ & $\begin{array}{l}155 \\
100 \%\end{array}$ \\
\hline \multicolumn{2}{|l|}{ Total } & $\begin{array}{l}142 \\
43.8 \%\end{array}$ & $\begin{array}{l}182 \\
56.2 \%\end{array}$ & $\begin{array}{l}324 \\
100 \%\end{array}$ \\
\hline
\end{tabular}

From the cross tabulation it can be determined that almost half of the respondents who have formed a relationship with the airlines were satisfied with the airlines' overall service $(49.7 \%)$, while the majority of respondents who have not formed a relationship with the airline were dissatisfied (62.6\%). The Pearson Chi-square test was performed to determine if a statistically significant association exists between whether respondents have formed a relationship with the airlines and their satisfaction with the airlines' services. The test realised an exceedance probability of $p 0.026$, indicating a statistically significant association between these variables. Hypothesis 2 should therefore be rejected as there is a statistically significant relationship between whether respondents have formed relationships with the domestic airlines and their satisfaction with the airlines' service. 
Relationship with, and Loyalty Towards, the Airlines (Hypothesis 3)

Respondents were asked to indicate if they were loyal towards the domestic airline they fly with the majority of the time. Slightly more respondents indicated that they were disloyal to the airline $(50.9 \%)$ than those who indicated that they were loyal $(49.07 \%)$. It was subsequently decided to determine if an association exists between whether respondents have formed a relationship with the domestic airline and their loyalty towards the airline. This analysis was done by means of a cross-tabulation, detailed in Table 3 (see Table $3 a$ in Annexure A for a detailed exposition of statistical values).

Table 3: A cross-tabulation between whether respondents have formed relationships with the airlines and their loyalty towards the airline

\begin{tabular}{|c|c|c|c|c|}
\hline & \multicolumn{2}{|c|}{ Whether relationship was formed } & \multirow[t]{2}{*}{ Total } \\
\hline & & $\begin{array}{l}\text { Have formed a } \\
\text { relationship }\end{array}$ & $\begin{array}{l}\text { Have not formed a } \\
\text { relationship }\end{array}$ & \\
\hline \multirow[t]{2}{*}{$\begin{array}{l}\text { Loyalty towards the } \\
\text { airline }\end{array}$} & Loyal & $\begin{array}{l}121 \\
76.1 \%\end{array}$ & $\begin{array}{l}38 \\
23.9 \%\end{array}$ & $\begin{array}{l}159 \\
100 \%\end{array}$ \\
\hline & Disloyal & $\begin{array}{l}21 \\
12.7 \% \\
\end{array}$ & $\begin{array}{l}144 \\
87.3 \% \\
\end{array}$ & $\begin{array}{l}165 \\
100 \% \\
\end{array}$ \\
\hline \multicolumn{2}{|l|}{ Total } & $\begin{array}{l}142 \\
43.8 \%\end{array}$ & $\begin{array}{l}182 \\
56.2 \%\end{array}$ & $\begin{array}{l}324 \\
100 \%\end{array}$ \\
\hline
\end{tabular}

From the cross-tabulation it can be seen that the majority of respondents who indicated that they have formed a relationship with the airline are loyal towards the airline $(76.1 \%)$, while the majority who indicated that they have not formed a relationship are disloyal towards the airlines (87.3\%). The Pearson Chi-square test was performed to determine if a statistically significant association exists between whether respondents have formed a relationship with the airline and their loyalty towards the airline. The test realised an exceedance probability of $p 0.000$, indicating a statistically significant association between these variables. Hypothesis $\mathbf{3}$ should therefore be rejected as there is a statistically significant association between whether respondents have formed relationships with the domestic airlines and whether they are loyal towards the airlines.

\section{Effect of Service Failure and Service Recovery (Hypothesis 4)}

From the literature discussion it could be deducted that service failures and organisations' service recovery efforts could influence customers' relationship with the organisation, as well as their satisfaction with the organisation, thereby impacting on customer retention. As the airline industry is particularly vulnerable to service failures, it was decided to determine what effect service failures, and specifically airlines' service recovery efforts, have on respondents' relationships with the airlines.

Respondents were requested to indicate whether they have experienced a service failure and to describe the nature of the failure. About $22 \%$ of the respondents said that they have experienced a service failure with a domestic airline. The majority of respondents $(62 \%)$ attributed a delayed flight as the reason for the service failure they experienced, followed by poor service (16.9\%) and lost luggage $(11.3 \%)$.

When asked how the airlines recovered from the service failure, the majority of respondents $(57.7 \%)$ indicated that the airline did nothing, offered discounts or vouchers for a next flight $(21.1 \%)$, booked the respondent on the next flight $(9.9 \%)$ or apologised for the failure $(8.5 \%)$. Considering the large percentage of respondents who indicated that the airlines did nothing to rectify the failure, it is not surprising that almost $68 \%$ of respondents who experienced a service failure were dissatisfied with the airlines' service recovery efforts. It therefore became apparent that it was necessary to determine what effect respondents' satisfaction with the airlines' service recovery had on their relationship with the airline. The effect of the service recovery on respondents' relationship with the airline was determined by asking respondents to indicate whether their relationship with the airline was unchanged or strengthened or broken or weakened. Table 4 illustrates the cross-tabulation between respondents' satisfaction with the airlines' service recovery efforts and the effect thereof on their relationship with the airline (see Table $4 a$ in Annexure A for a detailed exposition of statistical values). 
Table 4: A cross-tabulation between respondents' satisfaction with the airlines' service recovery and the effect on their relationship with the airline

\begin{tabular}{|l|l|l|l|l|}
\cline { 3 - 4 } \multicolumn{2}{c|}{} & \multicolumn{2}{|l|}{ Satisfaction with airlines' service recovery } & Total \\
\cline { 3 - 5 } \multicolumn{2}{c|}{} & Satisfied & Dissatisfied & \\
\hline $\begin{array}{l}\text { Effect } \\
\text { relationship } \\
\text { with airline }\end{array}$ & Broken or weakened & 6 & 41 & 47 \\
& & $12.8 \%$ & $87.2 \%$ & $100 \%$ \\
\cline { 2 - 5 } & Unchanged & 17 & 7 & 24 \\
\hline Total & strengthened & $70.8 \%$ & $29.2 \%$ & $100 \%$ \\
\hline & 23 & 48 & 71 \\
& $32.4 \%$ & $67.6 \%$ & $100 \%$ \\
\hline
\end{tabular}

From the cross-tabulation it can be seen that the majority of respondents who were dissatisfied with the airlines' service recovery efforts indicated that their relationship with the airline was either broken or weakened $(87.2 \%)$, while the majority of respondents who were satisfied were of the opinion that their relationship with the airline was unchanged or strengthened (70.8\%). A Chi-square test was performed to determine whether a statistically significant association exists between respondents' satisfaction with the airlines' service recovery efforts and their relationship with the airline. The test realised an exceedance probability of $p 0.000$, indicating a statistically significant association between the variables. Hypothesis 4 should therefore be rejected as there is a statistically significant association between respondents' satisfaction with airlines' service recovery efforts and the effect thereof on their relationships with the airlines.

\section{CONCLUSION AND MANAGERIAL IMPLICATIONS}

From the literature review it was observed that customer retention entails forming and maintaining longterm relationships with customers (Gerpott, et al., 2001:253) in an effort to continue doing business with them in the future (Murphy, et al., 2006:60\&144). Building relationships increases customer retention rates as relationships with customers result in higher levels of customer satisfaction as well as greater customer loyalty (Hansemark \& Albinsson, 2004:41; Keith et al., 2004:24-25; Reicheld, 1996:58).

Findings from this study suggest that, although the majority of respondents indicated that domestic South African airlines are trying to form relationships with them, somewhat less than half have actually formed such a relationship. However, despite this finding, it could be seen that significant associations exist between forming of a relationship and respondents' satisfaction with the airlines' overall service offering. Somewhat more than half of the respondents who indicated that airlines were trying to form relationships with them were satisfied with the airlines' overall service, while the majority who indicated that airlines were not trying to form relationships with them were dissatisfied with the airlines' overall service. Although slightly less than half of those respondents who indicated that they have formed a relationship with an airline were satisfied with this airline's overall service, more than half of respondents who have not formed a relationship with the airline they fly with most often, were dissatisfied with this airline's overall service.

It was also found that the majority of respondents who have formed a relationship with a domestic airline considered themselves loyal to the airline. The majority of respondents who have not formed a relationship with the airline, in contrast, indicated that they were disloyal towards the airline they fly with most often. It could be concluded that a statistically significant association exists between whether respondents have formed a relationship with an airline and their loyalty towards the airline.

The majority of respondents who experienced a service failure attributed the failure to a delayed flight, followed by poor service and lost luggage. These results are similar to that of Bamford and Xystouri (2005:314) whose research indicate that most passengers complained about flight cancellations, diversion of flights or delays as reasons for service failure. Since the majority of respondents indicated that the airline did nothing to recover the service failure, it was not surprising to find that most respondents were dissatisfied with the airlines' service recovery efforts. Most respondents who were dissatisfied with the airlines' service recovery indicated that their relationship with the airline was either 
weakened or broken, while the majority who were satisfied indicated that their relationship was unchanged or strengthened. A statistically significant association was found between respondents' satisfaction with airlines' service recovery efforts and their relationship with the airline.

By building relationships with their customers, organisations will increase customer satisfaction, and also increase customer loyalty, which will ultimately result in customer retention. Even if customers do not form a relationship with the organisation, the organisation's efforts to form a relationship with its customers could result in greater levels of customer satisfaction. Management should, however, also be aware that poor service recovery efforts to customers' experienced service failures, could negatively influence customers' relationships with the organisation. Conversely, should organisations provide satisfactory service recovery, it could strengthen the relationship with customers or at least leave the relationship unchanged.

It is recommended that South African airlines make a special effort to build relationships with their existing customers, rather than to continually try to acquire new customers. Before attempting to build relationships with customers, airlines should continuously offer quality service to increase customer satisfaction. Airlines should also have service recovery strategies in place and should act immediately in the event of a service failure to ensure that customers are not disappointed for a second time, thereby encouraging the forming and building of relationships. Airlines could also, in addition to offering loyalty programmes, try building relationships by, for example, training customer contact personnel (including call centre personnel, ground and cabin crews) to welcome repeat customers (identified by using existing information systems) and thanking them for their repeat business; offer express luggage and check-in services to repeat customers; offer repeat customers upgrades whenever available; give customers discounts for future flights to encourage repeat business; give preferential treatment to luggage of repeat customers when disembarking, thereby ensuring that they receive their luggage quicker than other passengers; provide immediate access to a supervisor in the event of a service failure; and waive administration costs (or at least a portion thereof) when repeat customers change their flights.

In conclusion it can be suggested that airlines, by building relationships with their customers, will have a higher probability of success due to increased customer satisfaction, will enjoy higher customer loyalty, and will experience greater customer retention.

\section{LIMITATIONS AND DIRECTIONS FOR FUTURE RESEARCH}

The limitations of this study include using a convenience sampling method and conducting the study at only one South African domestic airport, namely OR Tambo International. Conclusions can therefore only be drawn for those respondents who participated in the study and cannot be generalised to the larger population. Also, the study was performed over a relatively short period due to time and financial constraints. Recommendations for future research is to use a probability sampling method to ensure the results are representative of the population; replicate the study among international airline passengers; and performing the study in other countries to determine possible cultural differences. The study could be replicated in other South African service industries, especially those that are also prone to service failures.

\section{ACKNOWLEDGEMENT}

The authors would like to express their gratitude to Prof PJ (Flip) du Plessis (Emeritus Professor, UNISA) for his critical review and inputs while drafting this article. 


\section{REFERENCES}

Ahmad, R. \& Buttle, F. 2001. Customer retention: a potentially potent marketing management strategy. Journal of strategy marketing, 9(2001):29-45.

Ahmad, S. 2002. Service failures and customer defection: a closer look at online shopping experiences. Managing service quality, 12(1):19-29.

Ang, L. \& Buttle, F. 2006. Customer retention management processes. European journal of marketing, 40(1/2):83-99.

Associated Press. 2009. World airlines group forecasts big losses. MSNBC news, 24 Mar. http://www.msnbc.msn.com/id/29863129 Date of access: 22 Jun. 2009.

Bamford, D. \& Xystouri, T. 2005. A case study of service failure and recovery within an international airline. Managing Service Quality, 15(3):306-322.

Baron, S. \& Harris. K. 2003. Services marketing: text and cases. $2^{\text {nd }}$ ed. Houndmills: Palgrave.

Bejou, D. \& Palmer, A. 1998. Service failure and loyalty: an exploratory empirical study of airline customers. Journal of Services Marketing, 12(1):7-22.

Boshoff, C.A. \& Klemz, R.B. 2005. The importance of doing it right the second time: two experimental studies of service recovery. (Paper presented at Southern Africa Institute for Management Scientists Conference on $26-28$ Sept.) Bloemfontein.

Boshoff, C. \& Leong, J. 1998. Empowerment, attribution and apologising as dimensions of service recovery: an experimental study. International Journal of Service Industry Management, 9(1):24-47.

Boshoff. C. \& Staude, G. 2003. Satisfaction with service recovery: its measurement and its outcomes. South African Journal of Business Management, 34(3):9-16.

Buttle, F. 2004. Customer relationship management: concepts and tools. London: Elsevier ButterworthHeinemann.

Chan, H. \& Wan, L.C. 2008. Consumer responses to service failures: a resource preference model of cultural influences. Journal of International Marketing, 16(1):72-97.

Chi, C.G.Q. \& Qu, H. 2008. Examining the structural relationships of destination image, tourist satisfaction and destination loyalty: an integrated approach. Tourism Management, 29(2008):624-636.

Christopher, M., Payne, A. \& Ballantyne, D. 2002. Relationship marketing: creating shareholder value. Oxford: Butterworth-Heinemann.

Cooper, D.R. \& Schindler, P.S. 2008. Business research methods. $10^{\text {th }}$ ed. New York: McGraw-Hill.

Coye, R.W. 2004. Managing customer expectations in the service encounter. International Journal of Service Industry Management, 5(1):54-71.

Coyles, S. \& Gokey, T.C. 2005. Customer retention is not enough. Journal of Consumer Marketing, 22(2):101-105.

Cranage, D. 2004. Plan to do to right: and plan for recovery. International Journal of Contemporary Hospitality Management, 16(4):210-219. 
Curasi, C.F. \& Kennedy, K. 2002. From prisoners to apostles: a typology of repeat buyers and loyal customers in service businesses. Journal of services marketing, 16(4):322-341.

DeSouza, G. 1992. Designing a customer retention plan. The Journal of Business Strategy, 13(2):2428.

Eccles, G. \& Durand, P. 1998. Complaining customers, service recovery and continuous improvement. Managing service quality, 8(1):68-71.

Faulkner, M. 2003. Customer management excellence: successful strategies from service leaders. Chichester: Wiley.

Fečiková, I. 2004. An index method for measurement of customer satisfaction. The TQM Magazine, 16(1):57-66.

Gerpott, T.J., Rams, W. \& Schindler, A. 2001. Customer retention, loyalty, and satisfaction in the German mobile cellular telecommunications market. Telecommunications policy, 25(2001):249-269.

Gilbert, D. \& Wong, R.K.C. 2003. Passenger expectations and airline services: a Hong Kong based study. Tourism management, 24(2003):519-532.

Gopalakrishnan, R. 2009. Global airline losses to hit \$9bn in 2009. Mail \& Guardian Online. http:www.mg.co.za/article/2009-06-08-global-airline-losses-to-hit-9bn-in-2009 Date of access: 22 Jun. 2009.

Grönroos, C. 1990. Relationship marketing approach to the marketing function in service contexts: the marketing and organizational behavior influence. Journal of Business Research, 20(1):3-12.

Gursoy, D., Chen, M. \& Kim, H.J. 2005. The US airlines relative positioning based on attributes of service quality. Tourism Management, 26(2005):57-67.

Hansemark, O.C. \& Albinsson, M. 2004. Customer satisfaction and retention: the experiences of individual employees. Managing service quality, 14(1):40-57.

Hill, N. \& Alexander, J. 2002. Handbook of customer satisfaction and loyalty measurement. $2^{\text {nd }}$ ed. Burlington, VT:Gower.

Hoffman, K.D., Czinkota, M.R., Dickson, P.R., Dunne, P., Griffin, A., Hutt, M.D., Krishnan, B.C., Lusch, R.F., Ronkainen, I.A., Rosenbloom, B., Sheth, J.N., Shimp, T.A., Siguaw, J.A., Simpson, P.M., Speh, T.W. \& Urbany, J.E. 2005. Marketing: principles \& best practices. $3^{\text {rd }}$ ed. Mason, OH: Thomson SouthWestern.

Hui, T.K., Wan, D. \& Ho, A. 2007. Tourists' satisfaction, recommendation and revisiting Singapore. Tourism management, 28(2007):965-975.

Jones, T.O. \& Sasser, E. 1995. Why satisfied customers defect. Harvard business review, November/December:88-99.

Keith, J.E., Lee, D. \& Lee, R.G. 2004. The effect of relational exchange between the service provider and the customer on the customer's perception of value. Journal of relationship marketing, 3(1):3-33.

Kumar, V. \& Reinartz, W.J. 2006. Customer relationship management: a database approach. Hoboken, $\mathrm{NJ}$ : Wiley.

La, K.V. \& Kandampully, J. 2004. Market orientated learning and customer value enhancement through service recovery management. Managing Service Quality, 14(5):390-401. 
Lewis, B.R. \& McCann, P. 2004. Service failure and recovery: evidence from the hotel industry. International Journal of Contemporary Hospitality Management, 16(1):6-17.

Magnini, V.P. \& Ford, J.B. 2004. Service failure recovery in China. International Journal of Contemporary Hospitality Management, 16(5):279-286.

Malhotra, N.K. 2007. Marketing research: an applied orientation. $5^{\text {th }}$ ed. Upper Saddle River, NJ: Pearson Prentice Hall.

Martin-Consuegra, D., Molina, A. \& Esteban, A. 2007. An integrated model of price, satisfaction and loyalty: an empirical analysis in the service sector. Journal of Product and Brand Management, 16(7):459-468.

Mattila, A.S. \& Cranage, D. 2005. The impact of choice on fairness in the context of service recovery. Journal of Services Marketing, 19(5):271-279.

Maxham, J.G. (III). 2001. Service recovery's influence on consumer satisfaction, positive word-of-mouth, and purchase intentions. Journal of Business Research, 54(2001):11-24.

McDougall, H.G. \& Levesque, T. 2000. Customer satisfaction with services: putting perceived value into the equation. Journal of services marketing, 14(5):392-410.

McMullan, R. \& Gilmore, A. 2003. The conceptual development of customer loyalty measurement: a proposed scale. Journal of targeting, measurement and analysis for marketing, 11(3):230-243.

Miller, J.L., Craighead, C.W. \& Karwan, K.R. 2000. Service recovery: a framework and empirical investigation. Journal of Operations Management, 18(2000):387-400.

Murphy, J.A. 2001. The lifebelt: the definitive guide to managing customer retention. Chichester: Wiley.

Murphy, J.A., Burton, J., Gleaves, R. \& Kitshoff, J. 2006. Converting customer value: from retention to profit. Chichester: Wiley.

Page, M., Pitt. L., Berthon. P. \& Money, A. 1996. Analysing customer defections and their effects on corporate performance: the case of Indco. Journal of Marketing Management, 12(7):617-627.

Pakdil, F. \& Aydın, O. 2007. Expectations and perceptions in airline services: an analysis using weighted SERVQUAL scores. Journal of air transport management, 13(2007):229-237.

Patterson, P.G., Cowley, E. \& Prasongsukarn, K. 2006. Service failure recovery: the moderating impact of individual-level cultural value orientation on perceptions of justice. International Journal of Research in Marketing, 23(3):263-277.

Peelen, E. 2005. Customer relationship management. London: Prentice Hall Financial Times.

Ranaweera, C. \& Prabhu, J. 2003. The influence of satisfaction, trust and switching barriers on customer retention in a continuous purchasing setting. International journal of service industry management, 14(4):374-395.

Reichheld, F.F. 1996. Learning from customer defections: the customers you lose hold the information you need to succeed. Harvard business review, (1996):56-69, March/April.

Reid, S. 1987. Working with statistics: an introduction to quantitative methods for social scientists. Oxford: Polity Press. 
Reinartz, W.J. \& Kumar, V. 2003. The impact of customer relationship characteristics on profitable lifetime duration. Journal of marketing, 67(1):77-99.

Seawright, K.K., DeTienne, K.B., Bernhisel, M.P. \& Hoopes Larson, C.L. 2008. An empirical examination of service recovery design. Marketing Intelligence and Planning, 26(3):253-274.

Starmer-Smith, C. $2008 . \quad$ Nationwide Airlines suspends all flights. http://www.telegraph.co.uk/travel/travelnews/1913602/Nationwide-Airlines-suspends-all-flights.html Date of access: 30 Sept. 2008.

Theunissen, G. \& Sguazzin, A. 2008. Nationwide Airline halts operations on revenue slump (Update 2). http://www.bloomberg.com/apps/news?pid=20601116\&refer=Africa\&sid=a89wqby1i5Tc\# Date of access: 30 Sept. 2008.

Torres, E.N. \& Kline, S. 2006. From satisfaction to delight: a model for the hotel industry. International Journal of Contemporary Hospitality Management, 18(4):290-301.

Venetis, K.A. \& Ghauri, P.N. 2004. Service quality and customer retention: building long-term relationships. European Journal of Marketing, 38(11/12):1577-1598.

Xu, Y., Goedegebuure, R. \& van der Heijden, B. 2006. Customer perception, customer satisfaction, and customer loyalty within Chinese securities business: towards a mediation model for predicting customer behavior. Journal of relationship marketing, 5(4):79-104.

Yuksel, A., Kilinc, U.K. \& Yuksel, F. 2006. Cross-national analysis of hotel customers' attitudes toward complaining and their complaining behaviours. Tourism Management, 27(2006):11-24.

Zeithaml, V.A., Bitner, M.J. \& Gremler, D.D. 2009. Services marketing: integrating customer focus across the firm. $5^{\text {th }}$ ed. Boston, MA: McGraw-Hill Irwin.

Zikmund, W.G., McLeod, R. (Jr) \& Gilbert, F.W. 2003. Customer relationship management: integrating marketing strategy and information technology. Hoboken, $\mathrm{NJ}$ : Wiley. 


\section{ANNEXURE A: DETAILED EXPOSITION OF STATISTICAL VALUES}

Table 1a: Whether airlines are trying to form relationships with respondents and their satisfaction with the airlines' service

\begin{tabular}{|l|l|l|l|}
\hline Chi-Square Tests & Value & df & Asymp. Sig. (2-sided) \\
\hline Pearson Chi-Square & $20.212^{\mathrm{a}}$ & 1 & .000 \\
\hline Likelihood Ratio & 20.403 & 1 & .000 \\
\hline Linear-by-Linear Association & 20.149 & 1 & .000 \\
\hline N of Valid Cases & 324 & & \\
\hline
\end{tabular}

a. 0 cells $(.0 \%)$ have expected count less than 5 . The minimum expected count is 66.98

Table 2a: Whether respondents have formed relationships with the airlines and their satisfaction with the airlines' service

\begin{tabular}{|l|l|l|l|}
\hline Chi-Square Tests & Value & df & Asymp. Sig. (2-sided) \\
\hline Pearson Chi-Square & $4.956^{\mathrm{a}}$ & 1 & .026 \\
\hline Likelihood Ratio & 4.974 & 1 & .026 \\
\hline Linear-by-Linear Association & 4.941 & 1 & .026 \\
\hline N of Valid Cases & 324 & & \\
\hline
\end{tabular}

a. 0 cells $(.0 \%)$ have expected count less than 5 . The minimum expected count is 67.93 .

Table 3a: Whether respondents have formed relationships with the airlines and their loyalty towards the airlines

\begin{tabular}{|l|l|l|l|}
\hline Chi-Square Tests & Value & df & Asymp. Sig. (2-sided) \\
\hline Pearson Chi-Square & $132.093^{\mathrm{a}}$ & 1 & .000 \\
\hline Likelihood Ratio & 129.531 & 1 & .000 \\
\hline Linear-by-Linear Association & 131.685 & 1 & .000 \\
\hline N of Valid Cases & 324 & & \\
\hline
\end{tabular}

a. 0 cells $(.0 \%)$ have expected count less than 5 . The minimum expected count is 69.69 .

Table 4a: Respondents' satisfaction with airlines' service recovery efforts and the effect on their relationship with the airline

\section{Chi-Square Tests}

\begin{tabular}{|l|l|l|l|}
\hline & Value & df & Asymp. Sig. (2-sided) \\
\hline Pearson Chi-Square & $24.460^{\mathrm{a}}$ & 1 & .000 \\
\hline Likelihood Ratio & 24.558 & 1 & .000 \\
\hline Linear-by-Linear Association & 24.116 & 1 & .000 \\
\hline N of Valid Cases & 71 & & \\
\hline
\end{tabular}

a. 0 cells $(.0 \%)$ have expected count less than 5 . The minimum expected count is 7.77 . 